\title{
IO
}

\section{What Did You Bring?}

Documentation of the encampment activities through written records and visual images was extensive and well organized. This documentation was used to legitimate as well as advertise the encampment and its goals. Women media producers and artists from around the world recorded the events, people, and processes of the summer of protest. The major video project was that of the Boston Women's Video Collective, which covered the peace camp from the initial planning early in 1983 to its official ending on Labor Day, 1983.

Since Boston was covering all the encampment's major events, my video partner (Nancy Zucchino) and I decided to cover the everyday lives of the women who had come to participate. Instead of focusing on protests, we recorded mealtime activities, women preparing their camping areas, camp maintenance, and other routine events. We wandered through the encampment and asked the women, "What did you bring with you to the encampment?" We asked this open-ended question so that they could say whatever they wanted about their reasons for being there, the encampment's activities, or the living conditions. Many women expressed surprise at the neutrality of the question, noting that it did not have the same political nature as the questions asked by other interviewers.

The following answers to our question were recorded on videotape during interviews conducted by Zucchino and myself in early July and late August 1983 . The answers indicate the different types of women attending, their varied reasons for being there, their relationships with other women, and their expectations about the encampment's physical facilities and political activities.

Woman: What a question! You mean physically or spiritually or just answer the question? Well I brought a real curiosity and interest and I brought some experience with the nuclear freeze and WILPF. I don't 
know, I just came up here expecting to meet with people and learn some things and find some musicians. I'm a musician.

Woman: I brought with me a desire to see my daughter, who is here. And also a desire to share with other women some of their thoughts and views on peace and feminism.

Her daughter: And I brought all my worldly possessions. Which isn't much. I brought my cat, who lives with me in my tent, my mother who came to visit, and a willingness to put my self in a place where I really thought I could empower myself and grow.

Woman: I think in the abstract. A lot of garbage from the male chauvinist world that we're dealing with and talking about. And a lot of it that we weren't even aware of, that we're becoming aware of very quickly, and it's causing a lot of thinking. We just got here last night, but it's been a really already a very good mind-expanding experience.

Question: How long do you plan to stay?

Woman: We can only stay until Tuesday morning. So I guess we'll have to expand pretty fast [laughter]. But I guess that's the biggest thing I'd say on an abstract level. And a lot of interest in getting everything we can while we're here as far as experiences and broadening and more feelings about feminism and non-violence and direct action, and all that sort of thing.

Woman I: Only what was absolutely necessary. You want me to be more specific? A tent and sleeping bag and a change of clothes and three books, in case I got bored with one of them I wanted to be able to read another. And my journal, which goes with me everywhere, and food. I forgot to bring a cup, a couple of utensils and a tin plate.

Woman 2: Can I answer that? Jill has forgotten to mention that she brought her lover and her friend with her which is obviously the first thing of importance, right? And her political co-worker.

Woman I: And also, my bicycle. So that I could take off if I didn't want to be here.

Woman: What did I bring with me? A big desire to find out what the encampment was all about, to feel what it was like to be among so many women, that's what I brought with me, and a toothbrush.

Question: So, what did you find here?

Woman: I've never been in such a crowd of women, it's just been wonderful. There's a lot of solidarity and just this feeling of being 
encompassed by a very loving group. You know, noncompetitive, just a very loving group. It's been great.

Woman: I brought a lot of confusion. And I still have a lot of confusion, about exactly what the peace encampment is. I think it's confirmed my commitment to nuclear disarmament which is really good. I brought a lot of love. Got a lot of hugs. I had a great time last night; I was security until six in the morning with the walkie-talkie and that was great too.

Woman: Well, I've been traveling for about a week before I got here so my car is mainly full of dirty laundry. But I also have some books and particularly a book that I was reading to the people that I came with last night, a Margaret Atwood book. And some food, which I bought on the way down, because I heard that you couldn't buy food around here. And my cereal bowl.

Woman I: Sleeping bags, and clothes.

Woman 2: Food.

Woman I: Food, food, we brought a lot of food.

Woman 2: Artichoke hearts, cheese, salami, bread.

Woman 3: Only some of us eat salami.

Woman I: Some of us eat salami.

Woman 2: A salmon salad.

Woman I: We're going to donate it to the kitchen.

Woman 2: Yeah, whatever we have left over.

Woman I: That's one reason why we brought a lot.

Woman 2: I brought a book.

Woman I: And that's about it, all we brought. And each other.

Women in unison: Each other [laughing].

Woman 2: Like five of us.

Woman 3: And our car.

Woman I: Our car.

Women in unison: Which we can't get into! [laughing].

Woman r: Cause we lost the keys! So we might stick around for a little more time [laughing].

Woman: We're traveling for two weeks after this so we brought the kitchen sink. We brought the chairs, because we're going to a music festival. We brought food, we brought a mattress to sleep on, you know one of those inflatable ones that takes about ten hours to fill up. We brought a cooler with food in it, although the food is getting warm 
because the ice pack broke. What else is in our car? We heard it was going to go down to zero so I have my down parka. A little Sterno so that Judy can make her tea at night. And a lot of utensils to eat with, from Wendy's. Sterilized.

Woman: Spirits of love, and a lot of excitement. A real feeling of openness. A lot of support, for what's going on here. Sleeping bags, tent.

Her son (age I I or I 2): Well, obviously a car.

Woman: Lots of food. Actually we were going to bring a camera because my son wanted to do a mini-documentary and I was the one who left the film at home. Greetings from Syracuse, because there are a lot of women who are in support of what's going on here. Plus a map that was printed in the Herald-Journal to show us exactly how to get here.

Woman I: I brought my guitar. Food, clothes. My sisters.

Woman 2: No, we brought ourselves.

Woman I: No, I brought you. And a book to write in.

Woman 3 : I brought a shitload of diapers. Oh, some clothes and food. I have this little baby.

Woman I: I brought a book of Starhawk spells. I brought my basic food and water and books.

Woman 2: I brought some snacks because I knew there wouldn't be any here. I brought some books and a journal. It's really important to me to have that space and be able to keep in touch with all that, because I'm having a hard time doing that. That's another thing I should have brought with me was more time for myself.

Woman I: I brought a desire to learn more from women of color, who are here, and who have been leading the struggles in this country for so many generations. I feel I have a great deal to learn from them.

Woman 2: Lots of physical stuff that I really needed. I was feeling a little burdened by that, by having to think about where it is and such things. But the other aspects, curiosity, since I really didn't know what to expect when I got here. I had some expectations, and some of them have been borne out and some not. And I also had a desire to talk to people about those expectations and I guess I'm finding my opportunities kind of limited. There are people who have said several times at orientations and general meetings that it's very easy to feel like a fifth wheel here and I haven't found that that feeling has gone away. 
Question: Why is that?

Woman 2: Because it seems to me people who have been here for a while have already developed friendships and maybe don't take time to talk to people who are relatively new. And I just don't see very many people talking about things.

Question: Have you thought about bringing that up at a general meeting?

Woman 2: Well, I guess it could be done. I'm not sure, I've only had the experience of one general meeting, and it seems to be largely occupied with the mundane details of surviving here from day to day, and not very much occupied with any of the many reasons that we're here. I had been here almost twenty-four hours before anybody said anything at all about making a presence of some kind at the depot. I mean, granted it was a day that we had devoted to something that was very, very important; but I just thought it took quite a while.

Woman I: I'm studying to be a rabbi, which is one of the reasons why I brought some [religious things]. I really want women to know that women can be rabbis and there are about sixty-five women rabbis in the world right now.

Woman 2: The first generation.

Woman I: The first generation, ever, in history. So God willing, I'll be ordained in two years. It's a five-year program after a bachelor's degree. There was another woman here yesterday who was also studying with me, and it's great, it's really great to be here, and the women's community needs clerics and healers and lots of people so we'll all find our way to do it, but that's my way right now.

Woman: What did I bring with me? My cat. Well, you know, I can't leave home without my cat. My tent. And a lot of leaflets. And clothes and some food and my van, which is what I live in when I'm not living in my tent. A lot of despair, which has now been turned into hope. And myself. I thought this was going to be one of the political questions. I was all geared up to answer one of the political ones.

Woman I: What did we bring with us? Tissues!

Woman 2: Materially or spiritually?

Woman I: I brought tissues.

Woman 2: Did you bring enough for the whole camp?

Woman I: I have two boxes. That's all.

Woman 2: Oh well. One sheet a woman! 
Woman 3: Well, your usual basic tent, sleeping bag, clothes, towels, dishwashing coconut soap, tarot cards, three hundred T-shirts.

Woman 4: About thirty loaves of bread. We brought bread from Baba's bakery. Zucchini from the garden.

Woman I: Oh no, not more zucchini.

Several women speaking at same time: Red Magic markers. We brought our spirit! We brought journals. We brought books, we brought flashlights that don't work any longer. Yeah, we brought extra batteries. We brought insect repellent. A cooler. We brought our friends and coworkers. Peanut butter, tahini, bread, Triscuits, fruit, granola bars, and cantaloupes and the cantaloupe is almost gone. Would you like a piece?

Woman: I brought hair-cutting tools.

Woman: Pass me a tissue?

Woman: I brought my artwork, my skills, and I have been creating structures here. Let's see, my motherliness; I like being in the kitchen and cooking hundreds, for hundreds of people.

Woman: I brought my tent, my sleeping bag, my fiddle, a book to read, my water bottle, rain gear, just a raincoat, shorts and a bathing suit, too many heavy shirts, in case I got cold, my towel, I always bring my towel, some handkerchiefs, a small first aid kit, some money, my passport, some incense and a little crystal thing from Betty. And I brought one pretty, long fluffy dress, in case we ever go dancing or something, and some music books because I like to do that. And my handbook from the encampment, and some plain thirteen-cent postcards, in case I had to write to people and tell them I was arrested or something.

Woman: I brought a tent, and a bunch of camping gear, and a child and a friend, and her child, and some hopes for the future, and some ideas too. My ideas were that women could do something, that there was an upswelling movement for peace that was coming at the hand of woman, and I thought that we would all be here learning together what that looked like, what that meant.

Question: Have you seen that happening?

Woman: I've seen it a lot, I've seen a lot of women really dedicated to peace, and really giving it everything they had, to come up with ideas.

Woman: I brought a history of having become a little impatient with the very legal, accepted way of working, petitioning and lobbying con- 
gressmen. We even changed the congressman in our district because we didn't like his attitude towards the freeze. And the peace people and the environmental people changed our representation. It made us feel good for a while until we realized that we hadn't done anything about a single cutback in nuclear weapons production. And it became obvious to me that if I was going to respect myself as a peace worker I had to come here. I also brought three tents, a porta-pottie for the children's childcare area, a big cooler for the main kitchen, and my car which has been used by everybody and I feel good to be able to make positive, material contributions to the camp.

Woman: Oh, what did I bring with me? I brought some skills that I wanted to use, and I brought my guitar, and I brought this book that taught me how to make a wigwam and I did it. And I brought me. 